\title{
Menakar Faktor Penghambat Dalam Mewujudkan Kepastian Hukum Dibidang Pertanahan
}

\author{
Muhammad Akbar Middin 1 , Salle Salle ${ }^{2}$, Aan Aswari ${ }^{2 *}$ \\ ${ }^{1}$ Mahasiswa Fakultas Hukum, Universitas Muslim Indonesia \\ ${ }^{2}$ Fakultas Hukum, Universitas Muslim Indonesia \\ *Email Correspondensi: aanaswari@umi.ac.id \\ No. Handphone Correspondensi: (+62) 85341767070
}

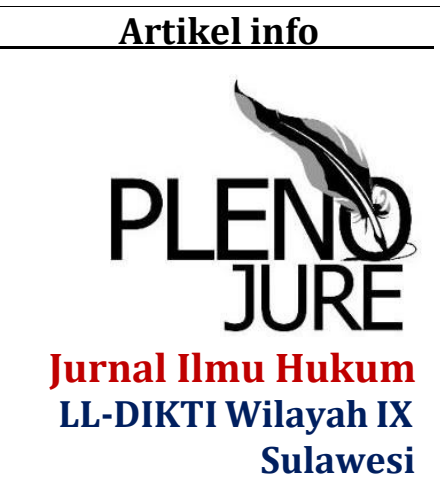

Artikel history:

Received; 08-10-2021

Revised: 21-10-2021

Accepted: 29-10-2021
Abstrak. Penelitian ini bertujuan untuk mengetahui faktorfaktor apa saja yang menghambat terjadinya pelaksanaan balik nama sertifikat hak milik dalam jual beli tanah di Desa Sanglepongan Kecamatan Curio Kabupaten Enrekang dan agar dapat menentukan upaya pihak Kantor Badan Pertanahan Nasional Kabupaten Enrekang terhadap masyarakat Desa Sanglepongan Kecamatan Curio Kabupaten Enrekang yang belum melakukan upaya perwujudan kepastian hukum disektor administrasi agraria. Kajian ini berupaya mendeskripsikan gambaran daerah pelosok sebuah provinsi yang masih perlu mendapatkan perhatian lebih dalam pemanfaatan hukum, sekaligus menunjukkan fenomena hukum tidak hanya wilayah perbatasan negeri saja yang masih bermasalah. Penelitian ini menggunakan metode penelitian hukum secara empiris dengan adanya data-data lapangan sebagai sumber data utama yang dirangkum dan dikumpulkan oleh peneliti melalui kuisioner dan wawancara. Hasil penelitian menunjukkan masyarakat pemilik tanah menyatakan beberapa faktor penyebab dari belum melakukan balik nama sertifikat hak milik atas tanah yang dibelinya adalah tidak mengetahui prosedur, biaya mahal, durasi pengurusan yang lama, merasa sistem administrasi yang berbelit-belit, dan tidak perlu melakukan balik nama dikarenakan masyarakat Desa Sanglepongan masih menganut sistem kepercayaan atau sistem adat, yaitu masyarakat menganggap masih memiliki ikatan keluarga sehingga tidak ada yang akan berani untuk menuntut atau memeperkarakan di kemudian hari. Meski demikian, temuan dari penelitian ini agar Badan Pertanahan Nasional perlu melakukan beragam tindakan yang dapat mengubah pola pikir masyarakat, diantaranya melakukan sosialisasi kepada masyarakat pentingnya sertifikat tanah dan tentang balik nama sertifikat tanah, dimana masyarakat telah difasilitasi beragam sarana dan prasarana untuk mendapatkan kepastian hukum.

Abstract. This study aims to find out what factors hinder the implementation of the transfer of title certificates in the sale and purchase of land in Sanglepongan Village, Curio District, 
Enrekang Regency and to determine the efforts of the Enrekang Regency National Land Agency Office towards the Sanglepongan Village community, Curio District, Enrekang Regency. who have not made efforts to realize legal certainty in the agrarian administration sector. This study seeks to describe the picture of remote areas of a province that still needs more attention in the use of the law, as well as showing legal phenomena, not only the border areas of the country that are still problematic. This study uses empirical legal research methods with field data as the main data source which is summarized and collected by researchers through questionnaires and interviews. The results showed that the landowners stated that several factors that caused them to not transfer the name of the certificate of title to the land they bought were not knowing the procedures, expensive fees, long duration of management, feeling that the administrative system was complicated, and there was no need to change the name because The Sanglepongan Village community still adheres to a belief system or customary system, namely the community considers they still have family ties so that no one will dare to sue or bring a lawsuit in the future. However, the findings of this study are that the National Land Agency needs to take various actions that can change the mindset of the community, including socializing the importance of land certificates and about the transfer of land certificates, where the community has been facilitated by various facilities and infrastructure to obtain legal certainty.

\section{Keywords:}

Kepastian Hukum;

Pertanahan; Balik

Nama Sertifikat;

Agraria;

\section{PENDAHULUAN}

Tanah semakin lama dirasakan seolah-olah menjadi sempit karena pertumbuhan masyarakat, sedangkan permintaan selalu bertambah.(Haris, 2009:4) Maka tidak heran kalau saat ini nilai tanah jadi meningkat tinggi dan menjadi komoditi yang menjanjikan. Tidak seimbangnya antara persediaan tanah dengan kebutuhan akan tanah itu telah menimbulkan berbagai persoalan yang banyak seginya, dan untuk memperoleh tanah dapat diperoleh dengan beberapa cara, yaitu permohonan hak dan pemindahan hak.

Perolehan hak atas tanah lebih sering dilakukan dengan pengalihan hak yaitu dengan melalui jual beli atau pewarisan. Peralihan hak adalah suatu perbuatan hukum yang bertujuan memindahkan hak antara lain: jual beli, hibah, tukar menukar, pemisahan dan pembagian harta bersama dan pemasukan dalam perusahaan. Salah satu hak penguasaan atas tanah yang diatur dalam Pasal 20 Undang-Undang No. 5 Tahun 1960 Tentang Peraturan Dasar Pokok- Pokok Agraria (selanjutnya disebut UUPA). Jika terjadi jual beli tanah, sebagian dari tanah pemilik tanah yang dijual akan dilakukan 
pendaftaran tanah yang kemudian diterbitkan suatu sertifikat tanah yang merupakan surat bukti hak kepemilikan. Sertifikat hak atas tanah merupakan perbuatan pemerintah bersegi satu berdasarkan peraturan perundangundangan untuk diterapkan pada peristiwa konkret menurut prosedur dan persyaratan tertentu.(Yunarko, 2013:189)

Fenomena menunjukkan seringkali dalam transaksi jual beli tanah yang tidak mengikuti prosedur jual beli tentu akan menimbulkan permasalahan baik dalam jangka pendek maupun jangka panjang. Pada jangka pendek pembeli mungkin tidak akan mengalami gugatan dari pihak lain, tetapi dalam jangka panjang pembeli akan mengalami gugatan dari pihak lain yang merasa memiliki atau dirugikan akan hak atas tanahnya, dan fenomena ini pun masih eksis hingga kini dan terbuktikan masih terdapat kajian-kajian ilmiah hukum yang menarik akhir-akhir ini.(Patni et al., 2020:316)

Desa Sanglepongan merupakan salah satu desa yang ada di Kecamatan Curio Kabupaten Enrekang dengan jumlah penduduk sebesar 1.538 jiwa dan memiliki luas wilayah sebesar $2.236 \mathrm{~km} 2$. Adapun tanah di Desa Sanglepongan digunakan untuk lahan pertanian, perkebunan dan kehutanan. Untuk luas lahan pertanian yang ada di Desa Sanglepongan 37.450 ha yang terbagi atas luas lahan garapan dan jenis pengairannya. Sedangkan luas lahan perkebunan di Desa Sanglepongan 78.530 ha dan luas hutan yang ada sebesar 12.760 ha yang terdiri atas hutan lindung, negara, hutan rakyat dan hutan tanaman rakyat.

Masyarakat Desa melakukan perbuatan hukum yaitu pengalihan hak atas tanah masih mengedepankan pola-pola tradisional, sehingga dalam struktur kepemilikannya hanya berdasarkan secara turun temurun. Namun dengan sejalannya perkembangan hukum agraria di Indonesia yang semakin menguatkan konsep kepastian hukum dalam setiap perbuatan hukum masyarakat, maka Undang-Undang Nomor 11 Tahun 2020 tentang Cipta Kerja mengubah Undang-Undang Nomor 30 Tahun 2014 tentang Administrasi Pemerintahan dan peraturan pelaksanaannya, maka pemerintah secara kongkrit telah membuat suatu kebijaksanaan untuk meningkatkan pelayanan bidang pertanahan yaitu pemberian sertifikat secara massal melalui Program Nasional Agraria (Prona).(Lubis, 2017:3)

Kegiatan yang diselenggarakan oleh pemerintah di bidang pertanahan dengan suatu subsidi di bidang pendaftaran tanah pada khususnya, yang berupa pensertifikatan tanah secara massal dalam rangka membantu masyarakat golongan ekonomi lemah sebagaimana legalitas tindakan ini didukung dengan adanya Peraturan Menteri Agraria dan Tata Ruang/ Kepala Badan Pertanahan Nasional Republik Indonesia Nomor 4 Tahun 2015 tentang Program Nasional Agraria (Prona). Namun, saat ini sesuai dengan kebutuhan masyarakat akan tanah maka tanah mengalami pemindahan hak melalui transaksi jual beli tanah, sehingga perbuatan hukum masyarakat pedesaan cenderung mengabaikan sisi kepastian hukum agar tujuannya mengelola tanah dengan cepat bisa terlaksana. Adapun transaksi jual tanah di Desa Sanglepongan berdasarkan hasil wawancara dengan Kepala Desa sebagai prapenelitian ini terhitung dari bulan Januari 2015 sampai dengan Maret 2021 sebanyak 72 transaksi dan sebagian besar warga belum melakukan balik nama yaitu sebesar $82 \%$ atau sebanyak 58 orang. Hal ini ditunjukkan dengan surat pernyataan jual-beli sebagai bukti kepemilikan atas tanah tersebut yang dilakukan tanpa akta PPAT melainkan di hadapan Kepala Desa Sanglepongan. 
Fenomena tersebut bertentangan dengan ketentuan jual beli tanah tentu adanya proses peralihan hak atas jual beli, bukti kwitansi lunas dari penjual atas pembelian tanah tidak bisa dijadikan dasar untuk melakukan balik nama (dalam hal ini peralihan hak) atas tanah harus dilakukan dengan adanya Akta Jual Beli (AJB) yang dibuat oleh PPAT. Pejabat Pembuat Akta Tanah (PPAT) mempunyai peran penting dalam pendaftaran tanah yaitu membantu Kepala Kantor Pertanahan Kabupaten/Kota untuk melaksanakan kegiatan-kegiatan tertentu dalam pendaftaran tanah. Namun jika di suatu daerah atau wilayah yang tidak memiliki PPAT, maka dapat menggunakan PPAT Sementara. Sesuai dengan ketentuan tentang Pejabat Pembuat Akta Tanah (PPAT) yang diatur dalam Pasal 7 ayat 2 Peraturan Pemerintah No. 24 Tahun 1997 yaitu "Untuk desa-desa dalam wilayah yang terpencil menteri dapat menunjuk PPAT Sementara".

Urgensi sebuah akta jual beli tanah dengan Akta PPAT yang menunjukkan terjadinya pemindahan hak milik atas tanah dan kepemilikan atas tanah, selain itu agar transaksi jual beli tanah dapat dipertanggungjawabkan sehingga tidak menimbulkan sengketa dikemudian harinya. Untuk itu proses balik nama sertifikat hak atas tanah tersebut sangatlah penting dilaksanakan bagi masingmasing pemilik tanah. Balik nama sertifikat hak atas tanah yang dilakukan dengan cara jual beli adalah perbuatan hukum pemindahan hak lainnya, kecuali pemindahan hak melalui lelang hanya dapat didaftarkan jika dibuktikan dengan akta yang dibuat oleh PPAT yang berwenang. Dengan demikian berarti setiap peralihan hak milik atas tanah, yang dilakukan dalam bentuk jual beli, tukar menukar atau hibah harus dibuat dihadapan PPAT, namun keadaan yang diharapkan sebagaimana amanah dari aturan yang mengakomodir sebuah perbuatan hukum dalam persoalan tanah pada Desa objek penelitian ini tidak terjadi, olehnya menjadi sebuah tindakan yang tidak logis dan dipandang cacat dalam perbuatan hukum,(Qamar et al., 2017:60) serta menurut penalaran hukum bahwa tindakan-tindakan ini akan mendapatkan konsekuensi yaitu batal demi hukum.

Adanya sistem pendaftaran tanah berupa balik nama sertifikat hak atas tanah merupakan pembuktian berlakunya atau eksistensi hak milik seseorang terhadap pihak ketiga. Pendaftaran akan menjadi bukti yang kuat bagi kepemilikan seseorang atas bidang tanah tertentu dengan status hak milik.(Ratih, 2021:12), (Muthallib, 2020:23) Namun berdasarkan hasil wwancara dalam penelitian ini masih terdapat beberapa warga di Desa Sanglepongan yang belum melakukan pelaksanaan balik nama sertifikat hak milik atas tanah sebagai tanda bukti kepemilikan yang kuat dikarenakan ada beberapa faktor penghambat.

Kondisi tersebut sangat disayangkan melihat begitu pentingnya kepastian hukum dalam setiap peralihan hak atas tanah sebagai akibat dari transaksi jual beli tanah yang sesuai dengan UUPA, maka pelaksanaan balik nama haruslah dilakukan oleh masyarakat untuk menghindari akibat yuridis yang harus dihadapi. Dengan demikian perlu adanya peran pemerintah dalam mensosialisasikan pentingnya pelaksanaan balik nama sertifikat hak milik dalam pendaftaran tanah agar masyarakat menjadi lebih faham dan jelas mengenai pendaftaran tanah serta terdorong untuk melakukan balik nama sertifikat hak milik atas tanah yang dibelinya agar memperoleh suatu jaminan kepastian hukum atas haknya. Olehnya, dalam penelitian ini penulis berupaya 
mengukur dari sebuah masalah dengan mempertanyakan hal apasajakah yang menjadi faktor penyebab belum terlaksananya balik nama sertifikat hak milik dalam jual beli tanah di Desa Sanglepongan Kecamatan Curio Kabupaten Enrekang, Sulawesi-Selatan.

\section{METODE}

Penelitan ini adalah penelitian hukum empiris yaitu penelitian dengan adanya data-data lapangan sebagai sumber data utama, seperti hasil wawancara dan observasi yang menggambarkan fenomena hukum berkenaan dengan kajian ini. Lokasi penelitian dilaksanakan di Desa Sanglepongan Kecamatan Curio Kabupaten Enrekang, dan memilih daerah karena dari survei sebelumnya lokasi penelitian yang terpilih ini sempat dilakukan pra-penelitian juga, pada saat peneliti melakukan kajian hukum yang lain pada daerah ini dan menemukan sebuah sumber masalah yang dapat dijadikan sebuah penelitian yang diharapkan dapat menjadi referensi bagi pembaca kajian hukum. Penelitian Kepustakaan (Liberary Research) dengan mempelajari literaturliteratur hukum, Undang-Undang, Peraturan-Peraturan, serta tulisan-tulisan yang berkaitan dengan masalah penelitian, selain itup enelitian lapangan (Field Research) dilakukan dengan cara langsung turun ke lapangan untuk mengamati permasalahan yang menjadi objek penelitian dalam rangka mendapatkan dan mengumpulkan data atau informasi yang berguna bagi pembahasan untuk sebuah bentuk pemecahan masalah dan referensi hukum bagi penelitian selanjutnya.

Pengumpulan data penelitian dilakukan dengan cara teknik komunikasi langsung yaitu penulis mengadakan hubungan secara langsung kepada responden dalam penelitin ini melalui wawancara dengan subjek-subjek tertentu yang penulis anggap dapat mendukung penelitian ini. Selain itu, dilakukan teknik komunikasi tidak langsung yaitu teknik pengumpulan data yang dilakukan dengan memberikan angket/quesioner yang berisikan pertanyaan-pertanyaan kepada responden, dalam hal ini pemilik tanah di Desa Sanglepongan Kecamatan Curio Kabupaten Enrekang. Penelitian ini menghimpun jumlah populasi adalah keseluruhan obyek yang akan diteliti dan yang akan menjadi populasi dalam penelitian ini adalah Kepala Kantor Pertanahan Kabupaten Enrekang dan pemilik tanah di Desa Sanglepongan Kecamatan Curio yang belum melakukan balik nama sebanyak 58 orang yang dapat terangkum sejak Bulan Januari 2015 sampai dengan Maret 2021. Sampel adalah bagian kecil dari populasi yang dipilih secara acak yang akan menjadi sumber data yang ada pada penelitian ini. Secara kongkrit, penulis dalam penelitian ini menggunakan purposive sampling yaitu pemilihan sekelompok subjek atas ciri-ciri atau sifat-sifat tertentu yang dipandang mempunyai sangkut paut yang erat dengan ciri-ciri atau sifat-sifat populasi yang sudah diketahui sebelumnya. Pada penelitian ini data dan informasi yang telah berhasil dikumpulkan dari hasil penelitian dianalisa dengan menggunakan metode analisis deskriptif kualitatif

\section{HASIL DAN PEMBAHASAN}

Terkait dengan status kepemilikan hak atas tanah, pemilik tanah di Desa Sanglepongan sebagian besar hak atas tanah tersebut berawal dari Hak Milik, sebagaimana dapat dilihat dalam tabel 1 di bawah ini: 
Pleno Jure, Vol 10 (2), Muhammad Akbar Middin, dkk, Menakar Faktor Penghambat...

Tabel 1. Status Kepemilikan Hak Tanah Responden

\begin{tabular}{clcc}
\hline No. & \multicolumn{1}{c}{ Alternatif } & Frekuensi & Presentase (\%) \\
\hline $\mathbf{1}$ & Hak Milik & 10 & $\mathbf{1 0 0}$ \\
$\mathbf{2}$ & Hak Pakai & 0 & $\mathbf{0}$ \\
$\mathbf{3}$ & Hak Guna Bangunan & 0 & $\mathbf{0}$ \\
$\mathbf{4}$ & Hak Guna Usaha & 0 & $\mathbf{0}$ \\
\hline & $\mathbf{N}=\mathbf{1 0}$ & $\mathbf{1 0}$ & $\mathbf{1 0 0}$ \\
\hline
\end{tabular}

Sumber Data: Hasil Penelitian Lapangan yang diolah

Tabel diatas menunjukkan bahwa seluruh responden (100\%) dalam penelitian ini memiliki tanah dengan kepemilikan/status hak atas tanah adalah Hak Milik (HM), hal ini telah sesuai dengan amanah regulasi menurut Pasal 20 UUPA bahwa Hak Milik adalah hak turun temurun, terkuat dan terpenuh yang dapat dipunyai orang atas tanah itu Hak Milik juga dapat beralih dan dialihkan kepada pihak lain. Hal ini sesuai dengan pernyataan responden mengenai cara memperoleh atau mendapatkan tanah tersebut. Sebagian besar responden menyatakan bahwa mendapatkan atau memperoleh tanah dengan cara jual beli mengingat tanah menjadi kebutuhan yang sangat penting bagi kehidupan manusia dan memiliki nilai yang tinggi. Selain itu ada juga sebagian responden yang menyatakan bahwa dalam memperoleh dan mendapatkan tanah tersebut dari hasil warisan mengingat hak milik turun temurun dapat diwarisi oleh ahli waris yang mempunyai tanah. Untuk lebih jelasnya dapat dilihat pada tabel 2 berikut:

Tabel 2. Cara Responden Memperoleh/Mendapatkan Tanah

\begin{tabular}{cccc}
\hline No & Alternatif & Frekuensi & Presentase (\%) \\
\hline $\mathbf{1}$ & Warisan & 4 & $\mathbf{4 0}$ \\
$\mathbf{2}$ & Jual Beli & 6 & $\mathbf{6 0}$ \\
$\mathbf{3}$ & Hibah & 0 & $\mathbf{0}$ \\
$\mathbf{4}$ & Wasiat & 0 & $\mathbf{0}$ \\
\hline & $\mathbf{N}=\mathbf{1 0}$ & $\mathbf{1 0}$ & $\mathbf{1 0 0}$
\end{tabular}

Sumber Data: Hasil Penelitian Lapangan yang diolah

Melihat dari tabel 2 di atas dapat diketahui bahwa jual beli merupakan cara terbanyak responden dalam memperoleh atau mendapatkan tanah yaitu sebanyak 6 responden atau sebesar 60\%. Hal ini dikarenakan dalam masyarakat kita, perolehan hak atas tanah lebih sering dilakukan dengan pemindahan hak yaitu dengan jual beli. Melakukan transaksi jual beli tanah sangat diharapkan antara penjual dan pembeli mengetahui dan melaksanakan prosedur dan persyaratan dalam jual beli tanah mengingat akan adanya perselisihan atau persengketaan akan hak atas tanah akibat meningkatnya kebutuhan manusia akan tanah. Data responden mengenai apakah mengetahui 
proses transaksi jual beli yang sesuai dengan ketentuan yang berlaku dalam jual beli tanah dapat dilihat pada tabel 3 berikut ini:

Tabel 3. Pengetahuan Responden Mengenai Transaksi Jual Beli yang Sudah Sesuai dengan Prosedur Jual Beli Tanah dan Prosedur Balik Nama

\begin{tabular}{ccc}
\hline Alternatif & Frekuensi & Presentase (\%) \\
\hline Sudah Mengetahui & 7 & 70 \\
Belum Mengetahui & 3 & 30 \\
\hline $\mathrm{N}=10$ & 10 & 100 \\
\hline
\end{tabular}

Sumber Data: Hasil Penelitian Lapangan yang diolah

Berdasarkan pernyataan pada tabel 3 di atas dapat diketahui bahwa sebagian transaksi jual beli tanah yang dilakukan warga Desa Sanglepongan sudah sesuai dengan prosedur jual beli tanah dan prosedur balik nama yang berlaku menurut Peraturan Pemerintah Nomor 18 Tahun 2021 tentang Hak Pengelolaan, Hak Atas Tanah, Satuan Rumah Susun, dan Pendaftaran Tanah sebagaimana perubahan atas Peraturan pemernitah Nomor 24 Tahun 1997 tentang Pendaftaran Tanah, yaitu sebanyak 70\% dan sebagian lagi masih belum sesuai dengan prosedur jual beli tanah dan prosedur balik nama yang berlaku menurut ketentuan tersebut yaitu sebanyak 30\% juga. Hasil wawancara kepada kepala kantor BPN yang menaungi wilayah objek penelitian setempat, faktor yang menyebabkan beberapa pemilik tanah di Desa Sanglepongan Kecamatan Curio tidak melakukan proses pembuatan Akta Jual Beli Tanah di hadapan PPAT disebabkan masyarakan menganut sistem kepercayaan dan juga sistem kekeluargaan.

Untuk memperoleh kembali status hak milik atas tanah tersebut, maka tanah yang diperoleh dari hasil warisan atau jual beli tersebut harus didaftarkan ulang meskipun sudah memiliki sertifikat namun masih atas nama pemilik yang lama atau sebelumnya. Oleh sebab itu perlu dilakukan perbuatan hukum yakni pendaftaran kepada Badan Pertanahan Nasional setempat guna peralihan hak atas tanah tersebut, atau dikenal dengan istilah balik nama. Namun melihat gambaran dari tabel 3 masih ada sebagian besar dari masyarakat pemilik tanah yang belum mengetahui prosedur balik nama sesuai dengan ketentuan yang berlaku. Hal ini ditunjukkan dengan masih banyaknya masyarakat yang belum memiliki sertifikat tanah dan hanya memiliki bukti kepemilikan tanah berupa Surat Pernyataan Pemilik sebelumnya bersama pemilik baru dan Sertifikat atas nama pemilik sebelumnya yag dikuasai oleh pemilik baru. Melihat kenyataan yang ada bahwa masih ada masyarakat yang belum mengetahui prosedur balik nama yang sesuai dengan ketentuan yang berlaku, tentu sebagian besar dari masyarakat pemilik tanah yang belum melakukan balik nama sertifikat hak milik atas tanah yang dibelinya. Untuk lebih jelasnya mengenai balik nama yang dilakukan oleh responden terhadap sertifikat hak milik atas tanah yang dibelinya dapat dilihat pada tabel di bawah ini: 
Pleno Jure, Vol 10 (2), Muhammad Akbar Middin, dkk, Menakar Faktor Penghambat...

Tabel 4. Balik Nama yang Dilakukan oleh Responden Terhadap Sertifikat Hak Milik Atas Tanah yang Dibeli

\begin{tabular}{cccc}
\hline No & Alternatif Balik Nama & Frekuensi & Presentase (\%) \\
\hline 1 & Sudah Dilakukan & 2 & 20 \\
2 & Belum Dilakukan & 8 & 80 \\
\hline & $\mathrm{N}=10$ & 10 & 100 \\
\hline
\end{tabular}

Sumber Data: Hasil Penelitian Lapangan yang diolah

Hasil dari tabel 4 dapat dilihat bahwa sebagian besar dari masyarakat pemilik tanah di Desa Sanglepongan yang belum melakukan balik nama sertifikat hak milik atas tanah yang dibelinya yaitu sebanyak 8 responden $(80 \%)$. Pelaksanaan balik nama sertifikat hak milik atas tanah yang masih banyak belum dilakukan oleh masyarakat pemilik tanah tentu memiliki beberapa faktor alasan penyebab tidak terlaksananya. Untuk lebih jelasnya alasan yang dimiliki para pemilik tanah di Desa Sanglepongan belum melakukan balik nama sertifikat hak milik atas tanah dapat dilihat pada tabel berikut:

Tabel 5. Faktor Penyebab Responden Belum Melakukan Balik Nama Sertifikat Hak Milik Atas Tanah yang Dibeli

\begin{tabular}{clcc}
\hline No & \multicolumn{1}{c}{ Alternatif } & Frekuensi & $\begin{array}{c}\text { Presentase } \\
\text { (\%) }\end{array}$ \\
\hline 1 & Tidak mengetahui prosedur & 1 & 10 \\
2 & Tidak memiliki biaya & 2 & 20 \\
3 & Urusannya memakan waktu & 2 & 20 \\
4 & Administrasi yang berbelit-belit & 0 & 0 \\
5 & Tidak perlu & 1 & 10 \\
6 & Jawaban 1,2,3,4,5 benar & 4 & 40 \\
\hline & $\mathrm{N}=10$ & 10 & 100 \\
\hline
\end{tabular}

Berdasarkan tabel 5 dijelaskan bahwa masyarakat pemilik tanah di Desa Sanglepongan sebagian menyatakan faktor penyebab dari belum melakukan balik nama sertifikat hak milik atas tanah yang dibelinya adalah tidak memiliki prosedur, tidak memiliki biaya, urusan memakan waktu yang lama, administrasi yang berbelit-belit dan tidak perlu melakukan balik nama sebanyak 4 responden (40\%). Sedangkan sebagiannya yaitu sebanyak 1 responden $(10 \%)$ menyatakan tidak mengetahui prosedur, sebanyak 2 responden $(20 \%)$ menyatakan tidak memiliki biaya, sebanyak 2 responden (20\%) menyatakan memakan waktu yang lama dan sebanyak 1 responden $(10 \%)$ menyatakan tidak perlu sebagai faktor penyebab dari masyarakat 
pemilik tanah belum melakukan balik nama sertifikat, karena ke tiga responden ini sudah punya pengalaman dalam melakukan balik nama sertifikat namun menganggap urusan atau prosesnya membutuhkan waktu yang lama. Sehingga menyebabkan masyakarat pemilik tanah yang lainnya enggan untuk melakukan proses balik nama sertifikat hak atas tanah yang dimilikinya, dan sosialisasi pengalaman balik nama ini lebih efektif dibanding pemerintah itu sendiri.

Kurangnya pemahaman mengenai prosedur dan syarat-syarat pelaksanaan balik nama sertifikat tentu saja berpengaruh juga terhadap keinginan atau upaya masyarakat pemilik tanah untuk melakukan balik nama sertifikat hak atas tanah yang dimilikinya. Selain itu masyarakat pemilik tanah juga memikirkan biaya yang dikeluarkan untuk pelaksanaan balik nama tersebut dan hal ini termasuk bagian dari informasi negatif yang diterima masyarakat berasal dari masyarakat yang telah memiliki pengalaman dalam mengurus sertifikat tanah. Mereka berfikir tentu mengeluarkan biaya yang besar untuk melaksanakan balik nama sertifikat hak atas tanah yang dibelinya. Hal ini disebabkan oleh anggapan adanya administrasi yang berbelit-belit sehingga urusannya memakan waktu yang lama, bertentangan dengan asas dan tujuan yang dinyatakan dalam aturan tentang pendaftaran tanah.(Tehupeiory, 2012) Berkaitan dengan faktor-faktor tersebut di atas maka sebagian besar dari masyarakat pemilik tanah menganggap pelaksanaan balik nama sertifikat hak milik atas tanah yang dibelinya tidak perlu dilakukan.(Puspita, 2019)

Kurangnya kesadaran tentang legalitas kepemilikan terhadap sebidang tanah di Desa Sanglepongan pada saat melakukan jual beli tidak sesuai prosedur jual beli. Kultur yang ada di masyarakat Desa Sanglepongan semakin menegaskan kembali bahwa masih bersifat asas kekeluargaan atau menganut sistem kekeluargaan, karena dalam suatu rumpun masyarakat menguasai tanah mengadakan peristiwa hukum, mereka bermasa bodoh dikarenakan masyarakat menganggap masih memiliki katan keluarga sehingga tidak ada yang akan berani untuk menuntut atau memeperkarakan di kemudian hari. Tanah dalam kepemilikannya jika tidak didaftarkan atau dilakukan balik nama akan mendapat akibat hukum. Untuk melihat apakah responden mengetahui akibat hukum sebagai konsekuensi bagi tanah yang belum didaftarkan ulang atau balik nama dapat dilihat pada tabel berikut di bawah ini:

Tabel 6. Akibat Hukum Bagi Pemegang Hak Milik Atas Tanah yang Belum Didaftarkan Ulang atau Balik Nama

\begin{tabular}{clcc}
\hline No & \multicolumn{1}{c}{ Alternatif } & Frekuensi & $\begin{array}{c}\text { Presentase } \\
\text { (\%) }\end{array}$ \\
\hline 1 & Tidak adanya kepastian hukum & 0 & 0 \\
2 & Adanya sengketa & 0 & 0 \\
3 & Jawaban 1 dan 2 benar & 10 & 100 \\
\hline & $\mathrm{N}=10$ & 10 & 100 \\
\hline
\end{tabular}

Sumber Data: Hasil Penelitian Lapangan yang diolah 
Sesuai tabel 6 di atas dapat diketahui bahwa sebagian besar masyarakat pemilik tanah sebanyak 10 responden atau sebesar $100 \%$ sudah mengetahui akibat hukum yang di dapat bagi tanah yang belum didaftarkan ulang atau balik nama. Hal ini dikarenakan bahwa sebagian besar pemilik tanah mendapatkan informasi bahwa sebidang tanah yang belum dilakukan balik nama akan mengakibatkan tidak adanya kepastian hukum atas tanah tersebut.

Perselisihan semakin terang dan berpotensi berlanjut jika terjadi peralihan hak kembali atas tanah tersebut dikarenakan sertifikat yang ada masih terdaftar atau tertera nama pemilik tanah yang lama, bukti yang dapat dijadikan dasar kepemilikan hak tidak cukup kuat jika masyarakat tetap menggunakan sistem yang menurut kebiasaan.(Yamin \& Zaidar, 2018:203) Sehingga dapat dikatakan bahwa sebagian besar dari masyarakat pemilik tanah di Desa Sanglepongan mengetahui akibat hukum yang didapat jika belum melakukan balik nama sertifikat dari pemilik tanah yang lama ke pemilik tanah yang baru. Namun dikarenakan adanya kendala dalam kurangnya pengetahuan mengenai prosedur dan syarat-syarat dalam pelaksanaan balik nama sertifikat maka sebagian dari masyarakat pemilik tanah enggan atau tidak mau untuk melakukan balik nama sertifikat hak milik atas tanah yang dimilikinya.

Sertifikat sebagai bukti tertulis yang terkuat menjadi dasar bagi seseorang dalam melakukan perbuatan hukum atas tanah yang dipunyai. Hal ini sesuai dengan ketentuan pasal 20 UUPA yang menentukan bahwa hak milik atas tanah merupakan hak turun temurun, terkuat dan terpenuh yang dapat dipunyai orang atas tanah. Oleh sebab itu, sertifikat harus segera dibalik nama guna menghindari perselisihan atau persengketaan yang terjadi atas hak tanah tersebut.

\section{KESIMPULAN}

Sebagian besar masyarakat masih menganut sistem kepercayaan dan sistem kekeluargaan dalam melakukan perbuatan hukum khususnya peralihan hak atas tanah, sehingga upaya yang dilakukan masih sebatas pernyataan kedua belah pihak tanpa melibatkan pihak yang berwenang, sehingga peralihan hak atas tanah tidak sesuai menurut prosedur yang berlaku. Budaya hukum masyarakat Desa dipengaruhi pengetahuan hukum masyarakat yang masih minim, sedangkan prinsip dalam pendaftaran tanah masih sangat ideal untuk membngun norma dan aturan hukum hingga zaman digital ini. Sesungguhnya keinginan masyarakat untuk mengurus bentuk kepastian hukum hak atas tanah sangat dipengaruhi oleh faktor pengetahuan hukum yang harusnya didapatkan dari sosialisasi BPN secara berkesinambungan, namun terdapat pengalaman negatif ketika mengurus balik nama oleh sebagian masyarakat, dan pengalaman negatif itu yang teringat dan tersebarluaskan informasinya ke masyarakat Desa.

\section{DAFTAR RUJUKAN}

Haris, A. (2009). Pengaruh Penatagunaan Tanah terhadap Keberhasilan Pembangunan Infrastruktur dan Ekonomi. In Bappenas. https://www.bappenas.go.id/files/3013/5228/3483/05abdul_200910 14131228_2260_0.pdf 
Lubis, A. E. C. (2017). Implementasi Kebijakan Peraturan Menteri Agraria Dan Tata Ruang Nomor 4 Tahun 2015 Tentang Program Nasional Agraria (Prona) Dalam Rangka Pelayanan Pembuatan Sertifikat Tanah Di Kantor Pertanahan Kota Medan [Universitas Muhammadiyah Sumatera Utara]. http://repository.umsu.ac.id/bitstream/123456789/4321/1/Implement asi Kebijakan Peraturan Menteri Agraria Dan Tata Ruang Nomor 4 Tahun 2015 Tentang Program Nas I O Nal Agraria \%28Prona\%29 Dalam Rangka Pela.pdf

Muthallib, A. (2020). Pengaruh Sertifikat Hak Atas Tanah Sebagai Alat Bukti Dalam Mencapai Kepastian Hukum. Jurisprudensi: Jurnal Ilmu Syariah, Perundang-Undangan, Dan Ekonomi Islam, 12(1), 21-43. https://doi.org/10.32505/jurisprudensi.v12i1.1673

Patni, I. G. A. M., Suwitra, I. M., \& Sukadana, I. K. (2020). Kedudukan Sumpah Pemutus dalam Pembuktian Sengketa Tanah Waris. Jurnal Konstruksi Hukum, 1(2), 315-319. https://doi.org/10.22225/jkh.2.1.2563.315-319

Puspita, D. (2019). Problematika Penerapan Asas Terjangkau Dalam Pendaftaran Tanah. Pena Justisia: Media Komunikasi Dan Kajian Hukum, 18(2), 108-117. https://doi.org/10.31941/pj.v18i2.1129

Qamar, N., Busthami, D., Aswari, A., \& Reza, F. S. (2017). Logika Hukum, Meretas Pikir dan Nalar (2nd ed.). CV. Sign. https://books.google.co.id/books?hl=en\&lr=\&id=p6cDwAAQBAJ\&oi=fnd\&pg=PR5\&dq=info:UkzQH4xxX_AJ:scholar.google. com\&ots=liBvB-wbb_\&sig=oe-

EUkBCP7md4eUOI6TI6KNpCJM\&redir_esc=y\#v=onepage\&q\&f=false

Ratih, N. R. (2021). Analisis Yuridis Sertifikat Tanah Hak Milik Elektronik (ECertificate) Demi Mewujudkan Kepastian Hukum. Jurnal Signifikan Humaniora, 2(4), 1-20. http://www.riset.unisma.ac.id/index.php/SIGN/article/view/12301

Tehupeiory, A. (2012). Pentingnya Pendaftaran Tanah di Indonesia (A. Andriansyah (ed.); I). Raih Asa Sukses. https://books.google.co.id/books?hl=id\&lr=\&id=0xj2CQAAQBAJ\&oi=fnd \&pg=PP1\&dq=pendaftaran+tanah\&ots=TkDZv1dqpj\&sig=4CbhcD8f_Zcb L4T4AeQqDcrtkrk\&redir_esc=y\#v=onepage\&q=pendaftaran tanah\&f=false

Yamin, M., \& Zaidar, Z. (2018). Pendaftaran Tanah Dalam Mewujudkan Kepastian Hukum Atas Kepemilikan Tanah Dan Upaya Meminimalisir Konflik Pertanahan. Jurnal Hukum Samudra Keadilan, 13(2), 201-210. https://doi.org/10.33059/jhsk.v13i2.911

Yunarko, B. (2013). Kedudukan Jabatan Dan Akta Pejabat Pembuat Akta Tanah Dalam Sengketa Di Peradilan Tata Usaha Negara. Perspektif, 18(3), 188. https://doi.org/10.30742/perspektif.v18i3.45 